\title{
COMPARATIVE ANALYSIS OF MODIFICATION OF BITUMEN BY USE OF POLY VINLY CHLORIDE AND ETHYL VINYL ACETATE
}

\author{
Shumank Deep Srivastava1, Syed Aqeel Ahmad ${ }^{2}$, Naveen Prakash Rao ${ }^{3}$, S.M. Ashraf Husain ${ }^{4}$ \\ ${ }^{I}$ M.Tech (CTM), AM ASCE Assistant Professor: Department of Civil Engineering, Integral University, \\ Shumank@iul.ac.in ; shumank2012@gmail.com \\ ${ }^{2}$ M.Plan, MIUT, Associate Professor: Department of Civil Engineering, Integral University, \\ Syedaqeel@iul.ac.in \\ ${ }^{3}$ B.Tech Student: Department of Civil Engineering Integral University, \\ Prakash.jhonson9@gmail.com \\ ${ }^{4}$ M.Tech, Assistant Professor: Department of Civil Engineering Integral University, \\ smah@iul.ac.in,
}

\begin{abstract}
With mass infrastructural development transportation engineering has transformed vital aspect of research due to its contribution in economical development. Bitumen being the binding material for roads appears to be a prime aspect of research; due to this various researches are being done to improve the quality of bitumen. The paper deals with study of modification of bitumen with Poly Vinyl Chloride and ethyl vinyl acetate and comparison of results obtained thereof.
\end{abstract}

Keywords — polymer modified bitumen, ageing charecterstics, thermoplastics, binding materials, quality

\section{INTRODUCTION}

Bitumen being an efficient adhesive binder is primarily utilized in construction of pavements. Exhaustive research has revealed that properties of bitumen can be improved by use of certain additives known as "modifiers" and the sample is known as "Modified Bitumen" and can be used in top layers of the pavement [1]. The usage of polymer modified bitumen has got following advantages:

- Lower susceptibility to temperature variations

- High resistance to deformation at higher temperatures

- Better age resistance properties

- Better binding quality

- Over all improved performance

\section{MOTIVATION FOR WORK}

In recent past a study has been done by Murphy $\mathrm{M}$. et al on the use of recycled polymers with an aim to find recycled polymer modified binders that would be similar to proven modified binders or that would augment the properties of 100 penetration grade bitumen [2]. Airey G.D. et al have worked on the effects of the interaction between a styrene-butadiene-styrene (SBS) modified bitumen and recycled crumb rubber on the mechanical performance of impact absorbing asphalt (IAA), an asphaltic material that has applications as a sports and safety surface [3].

\section{SAMPLE Preparation}

Samples of size $500 \mathrm{~g}$ were prepared using the following criterion:

- $\quad 95 \%$ concentration of Bitumen of VG 40 Grade

- $5 \%$ concentration of Modifier

The selection of modifier was made considering these points:

- Should be available in form of a non-biodegradable waste.

- Should increase the specific gravity of bitumen thereby increasing it water resistance

- Should be a thermoplastic

- The melting point should be between $160-190^{\circ} \mathrm{C}$

After preparation of sample it was subjected to testing of its aging characteristics. For this purpose the sample was subject to normal surroundings and has been kept in lab itself without application of any external agent and the testing schedule was fixed at:

- $2^{\text {nd }}$ day

- $6^{\text {th }}$ day

- $10^{\text {th }}$ day

- $14^{\text {th }}$ day

- $16^{\text {th }}$ day

- $20^{\text {th }}$ day

- $24^{\text {th }}$ day

- $28^{\text {th }}$ day

The test results have been presented in later sections. At the time of prepare the samples the temperature of bitumen was kept at around $210^{\circ} \mathrm{C}$ so the modifiers can be mixed easily in a molten state and can easily bind with bitumen. 


\section{TESTING OF SAMPLES}

Considering the properties of polymer modified bitumen as per IS 15462:2004 and VG-40 grade sample as per IS $73: 2013$ to test the sample using the following tests on the basis of its aging characteristics:

- Softening Point Test

- Penetration Test

- Ductility Test

\subsection{Softening Point Test}

The test results obtained for softening point and their comparative study is presented in table 1 .

Table 1: Result of Softening Point Test

\begin{tabular}{|l|c|c|}
\hline \multicolumn{1}{|c|}{ Age of sample } & PVC Sample & $\begin{array}{c}\text { Ethyl Vinyl Acetate } \\
\text { Sample }\end{array}$ \\
\hline $2^{\text {nd }}$ day & $67^{\circ} \mathrm{C}$ & $50^{\circ} \mathrm{C}$ \\
\hline $6^{\text {th }}$ day & $68.5^{\circ} \mathrm{C}$ & $50.55^{\circ} \mathrm{C}$ \\
\hline $10^{\text {th }}$ day & $70^{\circ} \mathrm{C}$ & $50.75^{\circ} \mathrm{C}$ \\
\hline $14^{\text {th }}$ day & $67.55^{\circ} \mathrm{C}$ & $50.81^{\circ} \mathrm{C}$ \\
\hline $16^{\text {th }}$ day & $68.79^{\circ} \mathrm{C}$ & $51^{\circ} \mathrm{C}$ \\
\hline $20^{\text {th }}$ day & $69.36^{\circ} \mathrm{C}$ & $50.82^{\circ} \mathrm{C}$ \\
\hline $24^{\text {th }}$ day & $68.66^{\circ} \mathrm{C}$ & $50.63^{\circ} \mathrm{C}$ \\
\hline $28^{\text {th }}$ day & $69.71^{\circ} \mathrm{C}$ & $50.81^{\circ} \mathrm{C}$ \\
\hline
\end{tabular}

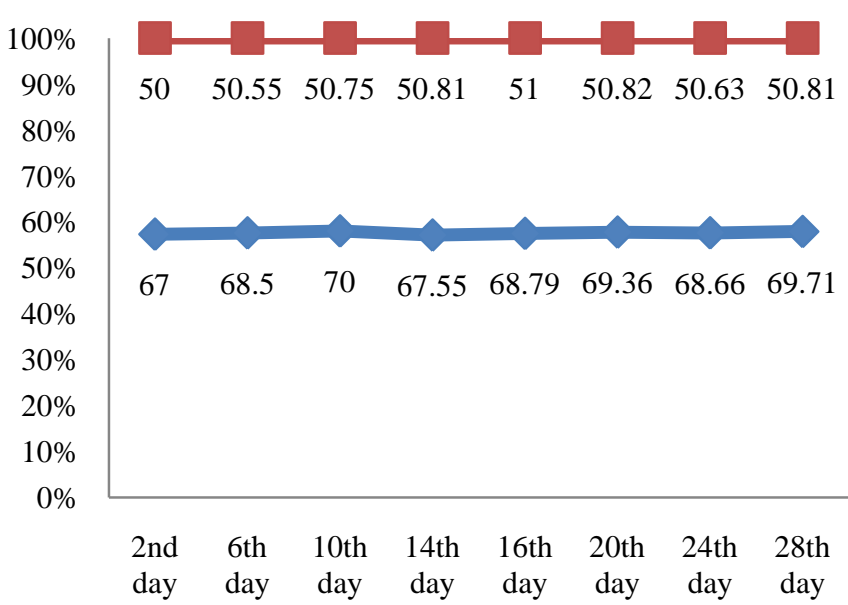

$\leadsto$ PVC Sample $\quad-$ Ethyl Vinyl Acetate Sample

Figure 1: Results of Softening Point Test

Mean of the results obtained is as under:

Poly Vinyl Chloride modified sample: $68.69^{\circ} \mathrm{C}$

Ethyl Vinyl Acetate modified sample: $50.67^{\circ} \mathrm{C}$

\subsection{Penetration TeSt}

The test results obtained for penetration test and their comparative study is presented in table 1.
Table 3: Result of Penetration Test

\begin{tabular}{|l|c|c|}
\hline \multicolumn{1}{|c|}{ Age of sample } & PVC Sample & $\begin{array}{c}\text { Ethyl Vinyl Acetate } \\
\text { Sample }\end{array}$ \\
\hline $2^{\text {nd }}$ day & 75 & 120 \\
\hline $6^{\text {th }}$ day & 68 & 95 \\
\hline $10^{\text {th }}$ day & 59 & 101 \\
\hline $14^{\text {th }}$ day & 58 & 102 \\
\hline $16^{\text {th }}$ day & 67 & 119 \\
\hline $20^{\text {th }}$ day & 87 & 113 \\
\hline $24^{\text {th }}$ day & 77 & 107 \\
\hline $28^{\text {th }}$ day & 73 & 106 \\
\hline
\end{tabular}

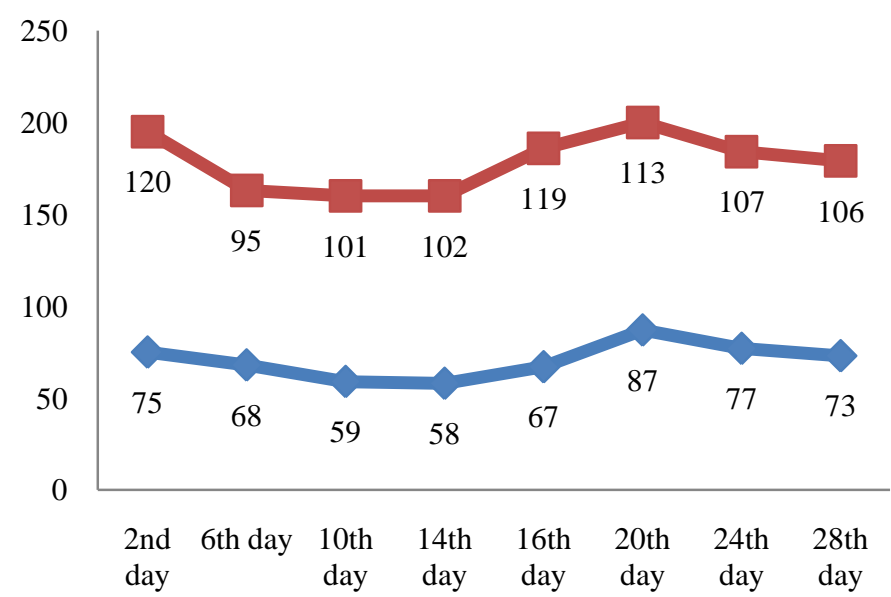

$\sim$ PVC Sample $\quad-$ Ethyl Vinyl Acetate Sample

Figure 2: Results of Penetration Test

Mean of the results obtained is as under:

Poly Vinyl Chloride modified sample: 70.5

Ethyl Vinyl Acetate modified sample: 107.87

\subsection{DuCTILITY TEST}

The test results obtained for penetration test and their comparative study is presented in table 1 .

Table 3: Result of Ductility Test

\begin{tabular}{|c|c|c|}
\hline $\begin{array}{c}\text { Age of } \\
\text { sample }\end{array}$ & PVC Sample & $\begin{array}{c}\text { Ethyl Vinyl Acetate } \\
\text { Sample }\end{array}$ \\
\hline $2^{\text {nd }}$ day & 33.1 & 58.9 \\
\hline $6^{\text {th }}$ day & 34.7 & 63.6 \\
\hline $10^{\text {th }}$ day & 33.5 & 61.3 \\
\hline $14^{\text {th }}$ day & 32.1 & 61.5 \\
\hline $16^{\text {th }}$ day & 35.4 & 61.9 \\
\hline $20^{\text {th }}$ day & 33.8 & 62.5 \\
\hline $24^{\text {th }}$ day & 33.9 & 59.9 \\
\hline $28^{\text {th }}$ day & 33.2 & 63.4 \\
\hline
\end{tabular}




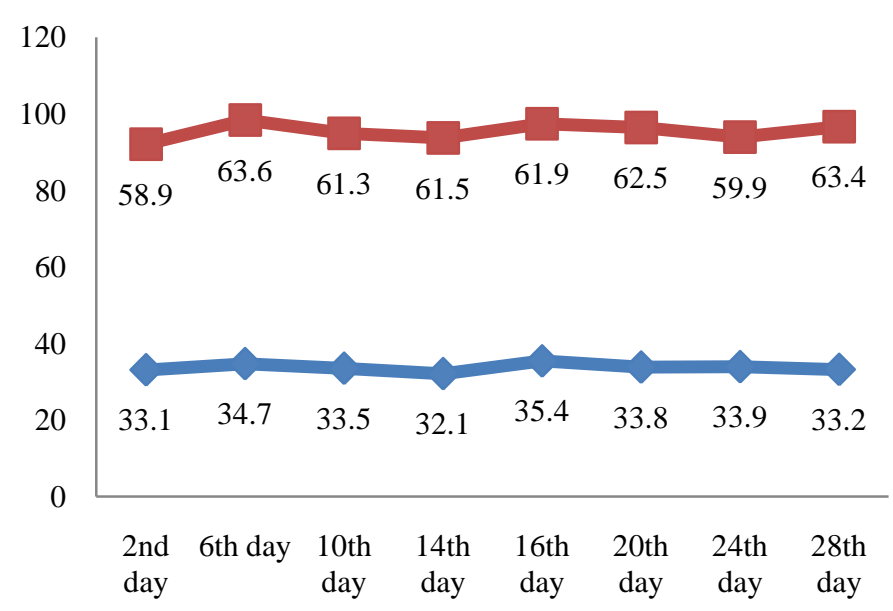

$\multimap$ PVC Sample $\quad-$ Ethyl Vinyl Acetate Sample

Figure 3: Results of Softening Point Test

Mean of the results obtained is as under:

Poly Vinyl Chloride modified sample: $33.71 \mathrm{~cm}$

Ethyl Vinyl Acetate modified sample: $61.63 \mathrm{~cm}$

\section{Conclusion}

Conclusively it could be remarked that experimental study done yet on the guidelines suggests that the sample belong to PMB (E) 70 class of polymer modified bitumen with reference to IS 15462:2004. Whereas as per IS 73:2013 it can be remarked that the properties i.e. ductility and penetration of VG 40 grade bitumen varied widely between that for VG 10 and VG 20 type of bitumen thus making it suitable for lower temperature also. And the softening point of the sample increased in case of PVC modified sample whereas it remained same in case of Ethyl Vinyl Acetate sample. But though softening point could be regarded as a classification parameter for polymer modified bitumen but an overall analysis of results of the test strongly recommends that ethyl vinyl acetate could prove to be a better modifier.

\section{REFRENCES}

[1] IRC SP 53:2010 Guidelines on use of modified bitumen in road construction.

[2] Murphy, M., O’Mahony, M., Lycett, C., \& Jamieson, I. (2001). Recycled Polymers for Use as bitumen modifiers. Journal of Materials in Civil Engineering, 13(4), 306-314.

[3] Airey, G. D., Singleton, T. M., \& Collop, A. C. (2002). Properties of Polymer Modified Bitumen after Rubber-Bitumen Interaction. Journal of Materials in Civil Engineering, 14(4), 344-354.

[4] IS 15462:2004 Polymer and rubber modified bitumen - specifications

[5] http://www.bitumenengineering.com/library/40library/testing/121-softening-point-test

[6] IS 12031978 Determination of Penetration

[7] IS 12021978 Determination of Specific Gravity

[8] IS 12081978 Determination of Ductility
[9] http://theconstructor.org/transportation/pavementdesign/

[10] IS 15462: 2004

[11] IS 73: 2013

\section{BIOGRAPHIES}

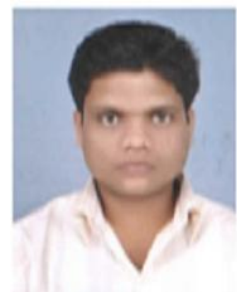

Shumank Deep Srivastava is working as an Assistant Professor in Department of Civil Engineering, Integral University. He has done his M.Tech in Construction Technology \& Management and Associate Member of American Society of Civil Engineers. He has got 4 research papers in various refereed journal and has presented 1 paper in a national conference, also he has co-authored 1 book.

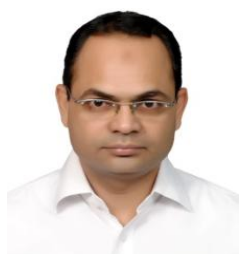

Dr. Syed Aqeel Ahmad is working as an Associate Professor in Department of Civil Engineering, Integral University. $\mathrm{He}$ is a prominent researcher in the field of Transportation Planning, to his credit he has got 21 publications at various refereed journals and national and international conferences and is presently have 4 consultancy projects in the field of transportation engineering. Also he is member of IRC, IUT, ITPI, IRT and ASCE.

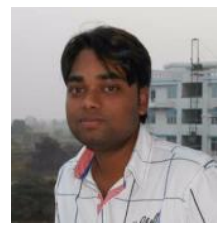

Naveen Prakash Rao has completed his B.Tech in Civil Engineering, from Integral University, Lucknow in the session 2014-15

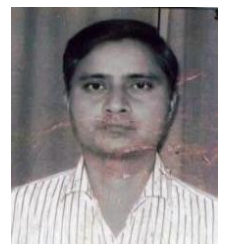

S.M. Ashraf Husain is working as an Assistant Professor, in Department of Civil Engineering at Integral University, Lucknow. He is associate member of ASCE and Institutions of Engineers, India. 